\title{
Maternal nutritional status in pastoral versus farming communities of West Pokot, Kenya: differences in iron and vitamin A status and body composition
}

Citation for published version (APA):

Ettyang, G. A., van Marken Lichtenbelt, W., Esamai, F., \& Saris, W. (2006). Maternal nutritional status in pastoral versus farming communities of West Pokot, Kenya: differences in iron and vitamin A status and body composition. Food and Nutrition Bulletin, 27(3), 228-235.

https://doi.org/10.1177/156482650602700305

Document status and date:

Published: 01/01/2006

DOI:

$10.1177 / 156482650602700305$

Document Version:

Publisher's PDF, also known as Version of record

Document license:

Taverne

Please check the document version of this publication:

- A submitted manuscript is the version of the article upon submission and before peer-review. There can be important differences between the submitted version and the official published version of record.

People interested in the research are advised to contact the author for the final version of the publication, or visit the DOI to the publisher's website.

- The final author version and the galley proof are versions of the publication after peer review.

- The final published version features the final layout of the paper including the volume, issue and page numbers.

Link to publication

\footnotetext{
General rights rights.

- You may freely distribute the URL identifying the publication in the public portal. please follow below link for the End User Agreement:

www.umlib.nl/taverne-license

Take down policy

If you believe that this document breaches copyright please contact us at:

repository@maastrichtuniversity.nl

providing details and we will investigate your claim.
}

Copyright and moral rights for the publications made accessible in the public portal are retained by the authors and/or other copyright owners and it is a condition of accessing publications that users recognise and abide by the legal requirements associated with these

- Users may download and print one copy of any publication from the public portal for the purpose of private study or research.

- You may not further distribute the material or use it for any profit-making activity or commercial gain

If the publication is distributed under the terms of Article 25fa of the Dutch Copyright Act, indicated by the "Taverne" license above, 


\title{
Maternal nutritional status in pastoral versus farming communities of West Pokot, Kenya: Differences in iron and vitamin A status and body composition
}

\author{
Grace Adisa Keverenge-Ettyang, Wauter van Marken Lichtenbelt, Fabian Esamai, \\ and Wim Saris
}

\begin{abstract}
Background. Underweight and micronutrient deficiencies are sequelae of the prevailing harsh living and economic conditions of women in sub-Saharan Africa. There are few data describing maternal nutritional status in these resource-poor settings. Provision of more effective modes of intervention requires that public health and nutrition policy at both the national and the multisectoral levels be based on community-specific nutritional and behavioral practices.

Objective. This longitudinal study investigated maternal micronutrient status in two remote, semiarid, rural communities that are ethnically similar but have distinctly different pastoral and farming lifestyles. We looked at differences in iron stores, vitamin A levels, and body composition of women in the third trimester of pregnancy and again at 4 months postpartum.
\end{abstract}

Methods. Complete data were collected from 113 pastoral and 110 farming Pokot women. Anthropometric measurements were taken, and serum ferritin and retinol levels were measured. Infants were weighed within 7 days of birth.

Results. Women from the farming community had significantly $(\mathrm{p}<.05)$ lower hemoglobin concentrations than women from the pastoral community during the third trimester of pregnancy. Pastoral women had significantly higher serum ferritin concentrations than

Grace Adisa Keverenge-Ettyang and Fabian Esamai are affiliated with the schools of Public Health and Medicine, Moi University, Eldoret, Kenya; Wauter van Marken Lichtenbelt and Wim Saris are affiliated with the Department of Human Biology, Maastricht University, Maastricht, The Netherlands.

This work was conducted in partial fulfillment of the doctoral degree requirements for Grace Adisa KeverengeEttyang in the Department of Human Biology, Maastricht University.

Please direct queries to the corresponding author: Dr. Grace Keverenge-Ettyang, Department of Epidemiology and Nutrition, School of Public Health, Moi University, PO Box 4606, Eldoret 30100, Kenya; e-mail: gaettyang@yahoo.com. farming women during the third trimester of pregnancy $(\mathrm{p}<.05)$ and at 4 months postpartum. There were no significant differences between pastoral and farming women in the percentage of women with serum retinol levels $<0.70 \mu \mathrm{mol} / \mathrm{L}$ during the third trimester of pregnancy (27.9\% [34/113] and 24.2\% [31/110], respectively) and at 4 months postpartum (29.2\% [33/113] and 30.9\% [34/110]) In the farming community, mean infant birthweight was significantly lower $(\mathrm{p}<.01)$ than in the pastoral community and a significantly higher $(\mathrm{p}<.05)$ proportion of newborns weighed less than 2.5 $\mathrm{kg}$. At 4 months postpartum, the percentage of body fat was significantly lower in pastoral women than in farming women.

Conclusions. Women from the farming community in West Pokot, Kenya, have lower iron stores during the third trimester of pregnancy than women in the pastoral community. In addition, the mean weight of their newborn infants is lower than that of infants in the pastoral community. These findings may be associated with differences in living conditions, which are usually harsher in farming than in pastoral communities.

Key words: Body composition, pregnancy outcome, serum ferritin, serum retinol

\section{Introduction}

In many rural societies in sub-Saharan Africa, the status and quality of life of women are inseparably linked to the environment and sociocultural systems that determine their way of life. Lifestyle, as determined by remote, drought-prone rural environments, has exposed pregnant and lactating women to low food intake levels and very limited access to health services. Though the resulting maternal deficiencies in micronutrients such as iron and vitamin A have well-recognized health consequences [1-4], the very few studies done in Kenya have mainly looked at maternal body composition $[5,6]$ and at pregnancy loss and outcome $[7,8]$. 
In the remote semiarid areas of rural Kenya, different communities may have similar ethnic backgrounds but divergent pastoral and farming ways of life. In both the pastoral and the farming lifestyles, women tend to be overworked due to too many demands on their time. For the pastoral woman, herding the family goats is a key responsibility. In farming communities, the family's food security depends on the woman's ability to dig, plant, weed, and harvest food crops.

In recent years, consecutive droughts have left families in both types of community at risk of starvation. The poor household food security has become a priority issue for both the government and the World Food Program (WFP). HIV/AIDS and endemic malaria are becoming increasingly significant public health problems. Though consumption is frequently limited, meat and blood remain the key foods in the diet of pastoral women. For this reason, a pastoral lifestyle is likely to have a more positive effect on maternal nutritional status during pregnancy and lactation than a farming lifestyle. The objective of this longitudinal study was therefore to investigate maternal micronutrient status in two rural communities that are ethnically similar but have distinctly different lifestyles. We looked at differences in iron and vitamin A stores and body composition of women in the third trimester of pregnancy and again at 4 months postpartum. Infants were weighed within 7 days of birth and the prevalence of birthweight $<2.5 \mathrm{~kg}$ was determined.

\section{Methods}

\section{Study area}

The Pokot community values its traditional way of life and has consistently remained largely unaffected by the forces of modernization [9]. Cattle occupy a central part of the economic and social life of the community. Although the farming and pastoral communities of Pokot reflect different ecological situations, their basic cultural outlook is the same. About $85 \%$ of the Pokot people are pastoralists. They move in seasonal cycles to search for water and pasture for their stock. The agricultural people of Pokot are grouped into sprawling villages made up of more permanent homesteads.

The study area was in West Pokot District. Two study clusters based on a farming and a pastoral lifestyle were identified. The farming cluster consisted of the Sobokwo and Kerelwa sublocations and the pastoral cluster of the Ortum, Morbus, and Shepkobegh sublocations. Administratively a sublocation is further divided into distinct villages administered by locally selected village elders. In the pastoral communities of these sublocations, the older men, women, and children remain at more permanent homesteads with some livestock, mainly goats, while the young men are constantly on the move with their cattle seeking grass and water. Because of the limited annual rainfall in the Pokot farming communities, these communities have developed an extensive system of furrow irrigation for the cultivation of maize, sorghum, and millet.

\section{Population}

The longitudinal study was carried out from October 2001 to August 2002. Approval for the research was obtained from both the Moi University ethical and research committee and the Government of Kenya. At the time of the study, a comprehensive census of households with pregnant and lactating women and children under the age of five had just been carried out by the assistant chief and village elders of the five sublocations. This was done in preparation for possible future government food distribution. Each sublocation was administered by an assistant chief and had 10 to 12 villages. An updated register of pregnant women was compiled with the help of the village elders and the traditional birth attendants (TBAs) residing in each village. A total of 310 pregnant women were registered. All of the women had very limited access to prenatal care. Estimation of gestational age, a fundamental issue when repeated anthropometric measurements are considered, requires special facilities not usually available in African villages [10].

In the selection of subjects for our study, the women registered as pregnant were further interviewed to obtain information on the date of their last menstrual period. Their expected date of confinement was based on the fact that pregnancy lasts about 266 days (38 weeks) from the day of fertilization. The expected date of confinement was determined by counting back 3 months from the first day of the last menstrual period and then adding 7 days and 1 year. Under the field conditions in which the study was conducted, the information on the women's last menstrual period was then used to estimate gestational age. Those estimated to be between 28 and 36 weeks pregnant were considered to be in the third trimester of pregnancy and were identified as suitable subjects for the study. They were advised that the expected date of confinement was only an estimate and that birth could occur within 2 weeks before or after the calculated date. Infants born within this period were considered to be term babies [10].

The women gave informed consent before participating in the longitudinal study. One hundred twenty-two women from 8 pastoral villages and 128 from 6 farming villages were examined and recruited for the study. Most of the babies were born at home. The TBA and a research assistant carefully maintained a record of birthdates for all the infants. 


\section{Anthropometric measurements and blood collection}

A precoded questionnaire was used to collect baseline information on demographic characteristics and pregnancy history. Anthropometric measurements made during pregnancy and lactation are expected to reflect both the nutritional status of the woman and, indirectly, growth of the fetus. Prepregnancy weight and prepregnancy body-mass index (the weight in kilograms divided by the square of the height in meters) are anthropometric measurements used to predict the risk of preterm delivery. In developing countries, prepregnancy values of maternal weight, height, or skinfold thickness are only seldom available. On the basis of the information provided by the World Health Organization (WHO) collaborative study [11] for anthropometric measurements made only once during pregnancy, mid-upper-arm circumference (MUAC), height, weight at any stage during pregnancy, and weight-for-height were identified as being of possible value for predicting maternal and fetal outcomes. MUAC is largely independent of gestational age and may be regarded as a proxy indicator of maternal prepregnancy weight or early pregnancy weight [12]. In addition, short maternal height has been associated with an increased risk of intrauterine growth retardation in several populations, and cutoff points between 140 and $150 \mathrm{~cm}$ have been proposed for screening [12].

The mother's body weight was measured to the nearest $0.1 \mathrm{~kg}$ with a calibrated electronic scale (SECA, Hamburg, Germany), and her height was measured to the nearest $0.1 \mathrm{~cm}$ with a height meter. A Holtain skinfold thickness caliper (Holtain, Croswell, UK) was used to make quadruple measurements of biceps, triceps, suprailiac, and subscapular skinfold thickness, which were used to determine maternal fat mass, percentage of body fat, and fat-free mass [13]. MUAC was measured with a nonextensible tape measure (UNICEF version). Repeated measurements were carried out by the same investigator. Low birthweight is an indicator of infant mortality risk, and in some populations a proportion of low-birthweight infants are a result of maternal undernutrition. In certain settings, however, improvement of maternal nutritional status may have no significant impact on infant mortality. Similarly, weight gain may be poor among pregnant women in a population with a high incidence of morbidity during pregnancy, and morbidity during pregnancy may have important effects on fetal development. Results from the WHO collaborative study [11] show that there is a strong correlation between a single measure of maternal weight late in pregnancy and the incidence of small-for-gestational age and low-birthweight infants. In this study, in order to determine pregnancy outcome, the infants were weighed at birth or within 7 days after birth. The infant's body weight was measured to the nearest $0.1 \mathrm{~kg}$ with a baby-weighing scale (SECA,
Hamburg, Germany). There is evidence that poor postpartum status, as reflected in low body-mass index, is associated with poor lactation performance and poor infant growth, which suggests that body-mass index may be a useful indicator of postpartum nutritional status. Other factors likely to affect maternal health and for which we were not able to collect accurate data would include illness, food intake, and chronic diseases.

A nonfasting venous blood sample of $5 \mathrm{~mL}$ was collected from each woman during the third trimester of pregnancy and at 4 months postpartum and divided into plain (trace element free) and EDTA vacutainer (Becton Dickinson, Franklin Lakes, NJ, USA). The samples were stored on ice for transportation to the West Pokot Kapenguria District Hospital laboratory. The serum was separated for 15 minutes at 3,000 rpm, aliquoted, and frozen overnight at $-20^{\circ} \mathrm{C}$ in the West Pokot Kapenguria District Hospital within 3 to 5 hours of sample collection. The next day the frozen samples were transported on dry ice to the Moi University laboratories in Eldoret, where they were stored at $-70^{\circ}$ $\mathrm{C}$ until analysis for serum retinol and ferritin.

\section{Biochemical analysis}

A Coulter counter model 560 (Coulter Electronics, Luton, England) was used to determine hemoglobin concentration and hematocrit. Serum retinol concentration was determined by high-performance liquid chromatography. Serum ferritin was measured by enzyme-linked immunoassay (ELISA) with a commercial kit (Boehringer Mannheim Immundiagnostike, Mannheim, Germany). A cutoff hemoglobin concentration of less than $110 \mathrm{~g} / \mathrm{L}$ was considered to be low and possibly linked to anemia $[1,13]$. Iron stores were characterized on the basis of serum ferritin concentration as severely depleted $(<12 \mu \mathrm{g} / \mathrm{L})$, marginally depleted $(12-29 \mu \mathrm{g} / \mathrm{L})$, or normal $(\geq 30$ $\mu \mathrm{g} / \mathrm{L})[14]$. Vitamin A status was characterized according to serum retinol concentration as deficient $(<0.35$ $\mu \mathrm{mol} / \mathrm{L}[10 \mu \mathrm{g} / \mathrm{dL}])$ or marginal $(0.35-0.70 \mu \mathrm{mol} / \mathrm{L}$ $[20 \mu \mathrm{g} / \mathrm{dL}])[15]$.

\section{Statistical analysis}

All statistical analyses were performed with the SPSS software package (Windows version 11.1); a $p$ value $<.05$ was considered to indicate statistical significance. Normality of data distribution was checked by visual evaluation with the use of a histogram and the Kolmogorov-Smirnov test of normality. The Pearson chisquare and independent-samples $t$-test were used to compare groups for significant differences. Odds ratios were used to estimate the relative risk of undernutrition in pastoral as compared with farming communities. 


\section{Results}

\section{Characteristics of subjects}

A total of 250 women from pastoral and farming villages who were in the third trimester of pregnancy were enrolled in the study. Of the original cohort, 116 women from pastoral villages and 114 from farming villages were examined at approximately 4 months postpartum. Fifty-three percent of woman from the pastoral communities and $54 \%$ of those from the farming communities had no formal schooling. The percentage of women who were primiparous was $10.7 \%$ in the pastoral communities and $8.5 \%$ in the farming communities; $22 \%$ of women in the pastoral communities and $22.7 \%$ of those in the farming communities had more than 4 children; and 39\% of those in the pastoral communities and $24 \%$ of those in the farming communities had at least one child under 24 months of age. Among women from the pastoral communities, 122 pregnancies resulted in 116 births; among women from the farming communities, there were 128 pregnancies and 114 births. Complete data were obtained from 113 women from pastoral communities $(92 \%)$ and 110 women from farming communities $(85 \%)$.

TABLE 1. Body composition and pregnancy outcome of pastoral and farming Pokot women during the third trimester of pregnancy and 4 months after delivery (lactation) (mean $\pm \mathrm{SD})^{a}$

\begin{tabular}{|l|c|c|}
\hline Characteristic & Pastoralists & Farmers \\
\hline Age (yr) & $26.8 \pm 5.8$ & $26.0 \pm 6.2$ \\
Education (yr) & $2.0 \pm 2.6$ & $2.2 \pm 3.1$ \\
Parity ${ }^{b}$ & $3 \pm 2$ & $3 \pm 2$ \\
Height $(\mathrm{cm})$ & $160 \pm 5.6$ & $160 \pm 6.8$ \\
Weight $(\mathrm{kg})$ & & \\
$\quad$ Pregnancy & $51.9 \pm 5.5$ & $51.6 \pm 7.1$ \\
$\quad$ Lactation & $50.0 \pm 6.3$ & $51.1 \pm 7.1$ \\
BMI (kg/m $\left.{ }^{2}\right)$ & & \\
$\quad$ Lactation & $19.7 \pm 2.1$ & $19.8 \pm 2.6$ \\
\% BF & & \\
$\quad$ Pregnancy & $21.7 \pm 3.8$ & $22.7 \pm 4.5$ \\
$\quad$ Lactation & $24.2 \pm 5.7$ & $25.9 \pm 5.1$ \\
FFM (kg) & & \\
Pregnancy & $40.5 \pm 3.9$ & $39.7 \pm 4.7$ \\
Lactation & $37.7 \pm 3.7$ & $37.6 \pm 4.1$ \\
Infant weight $(\mathrm{kg})^{c *}$ & $2.9 \pm 0.4$ & $2.8 \pm 0.4$ \\
\hline
\end{tabular}

BMI, body-mass index; \%BF, percentage body fat; FFM, fat-free mass

${ }^{*} p<.05$; (independent $t$-test)

a. There were 122 pregnant and 113 lactating pastoral women and 128 pregnant and 110 lactating farming women.

b. Parity is the total number of live births.

c. Infants were weighed within 7 days after birth.

\section{Body composition and pregnancy outcome}

Descriptive statistics for maternal body composition and pregnancy outcome during the third trimester of pregnancy and at 4 months postpartum are given in table 1. The proportion of women with a low bodymass index $\left(<18.5 \mathrm{~m} / \mathrm{kg}^{2}\right)$ at 4 months postpartum in farming and pastoral communities was $23 \%$ and $26.4 \%$, respectively. At 4 months postpartum, the mean percentage of body fat was significantly $(p<.05$, $t$-test) lower in pastoral women (table 1). The mean infant weight measured within 7 days after birth as an indicator of pregnancy outcome was $2.856 \pm 0.314$ (SD) $\mathrm{kg} ; 60 \%$ of the infants were male. The percentage of infants weighing less than $2.5 \mathrm{~kg}$ was $16.8 \%$ in the pastoral and $31.3 \%$ in the farming communities. The mean infant weight was significantly $(p<.01, t$-test) lower in the farming than in the pastoral communities (table 1). A significant ( $p<.05, \chi^{2}$ test) proportion of the newborns in the farming communities weighed less than $2.5 \mathrm{~kg}$ (fig. 1). Two children in the pastoral communities and five in the farming communities died soon after birth. The estimated relative risk of death was 2.4 times greater for infants born in the farming communities than for those born in the pastoral communities, probably because of the harsher living conditions in the farming communities.

\section{Iron and vitamin A status}

During the third trimester of pregnancy, the mean hemoglobin concentration was significantly $(p<.05$, $t$-test) lower in the pastoral than in the farming women (table 2). The percentage of women with low hemoglobin concentrations $(<110 \mathrm{~g} / \mathrm{L})$ in the third trimester was $42.2 \%$ in the pastoral communities and $21.8 \%$ in

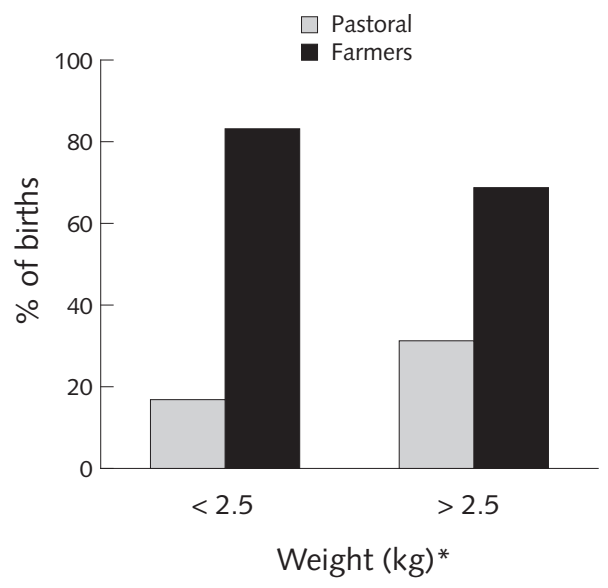

FIG. 1. Pregnancy outcomes: percentages of infants weighing less than and more than $2.5 \mathrm{~kg}$ born to pastoral and farming women

${ }^{*}$ Pearson $\chi^{2}, p<.01$ 
the farming communities (table 3 ). In the pastoral communities, a significant $\left(p<.01, \chi^{2}\right.$ test $)$ proportion of women had a reduced hemoglobin concentration during the third trimester of pregnancy. The mean serum ferritin concentration during the third trimester of pregnancy $(p<.05, t$-test) and at 4 months postpartum $(p<.01, t$-test) was significantly higher in the pastoral women than in the women from the farming communities (table 2). In the third trimester of pregnancy and at 4 months postpartum, the mean serum retinol concentration and the percentage of women with reduced vitamin A status did not significantly differ between the two communities (tables $\mathbf{2}$ and $\mathbf{3}$ ).

TABLE 2. Biochemical characteristics of pastoral and farming Pokot women during the third trimester of pregnancy and 4 months after delivery (lactation) (mean $\pm \mathrm{SD})^{a}$

\begin{tabular}{|l|c|c|}
\hline Characteristic & Pastoralists & Farmers \\
\hline $\begin{array}{l}\text { Hemoglobin }(\mathrm{g} / \mathrm{L}) \\
\quad \text { Pregnancy }\end{array}$ & $119 \pm 11.3$ & $124 \pm 15.0$ \\
$\quad$ Lactation & $118 \pm 10.0$ & $119 \pm 13.0$ \\
Hematocrit & $33 \pm 3.95$ & $32 \pm 5.42$ \\
$\quad$ Pregnancy & $34 \pm 2.71$ & $34 \pm 2.36$ \\
$\quad$ Lactation & & \\
Serum ferritin $(\mu \mathrm{g} / \mathrm{L})$ & $25.8 \pm 4.82$ & $24.4 \pm 4.87$ \\
$\quad$ Pregnancy & $18.5 \pm 4.80$ & $16.9 \pm 4.38$ \\
$\quad$ Lactation & & \\
Serum retinol $(\mu \mathrm{mol} / \mathrm{L})$ & & \\
$\quad$ Pregnancy & $0.92 \pm 0.43$ & $0.92 \pm 0.35$ \\
$\quad$ Lactation & $1.09 \pm 0.47$ & $1.11 \pm 0.50$ \\
\hline
\end{tabular}

${ }^{\star} p<.05 ;{ }^{* *} p<.01$ (independent $t$-test)

a. There were 122 pregnant and 113 lactating pastoral women and 128 pregnant and 110 lactating farming women.

\section{Discussion}

Communities and individuals become vulnerable to undernutrition depending on their geographic and social characteristics, which influence livelihood opportunities. It cannot be assumed that figures that portray the national prevalence of undernutrition necessarily provide an accurate reflection of the plight of individual households in a remote district within a wider region.

There is a paucity of literature based on comprehensive empirical work at the community and individual levels. Though not frequently done, targeting interventions to particular geographic areas or socioeconomic groups is the most common and best-known application of anthropometric indicators. One of our aims as researchers was to facilitate future targeting for equity those deprived of access to social, health, and nutrition services. In economically disadvantaged populations, short stature in adults could also be used as an indicator of socioeconomic inequality. As they relate to maternal anthropometry, socioeconomic indicators would include body-mass index standardized for stage of pregnancy or measured during lactation as an overall indicator of the factors that affect women's energy balance [11]. Key among these are adequacy of food intake and morbidity experience coupled with a heavy workload and reproductive demands.

In the Pokot communities, inadequate food intake could be due to a number of factors. In the pastoral communities, the number of cattle that a person owns is a critical factor that determines the frequency of consumption of milk, blood, and meat. These foods are more nutrient-dense and more continually available than foods in the farming communities, especially during a drought. To supplement this diet, income from the sale of animals is used to buy maize. The main food crops in the farming communities are white

TABLE 3. Proportion of pastoral and farming Pokot women with low hemoglobin, serum ferritin, and serum retinol during the third trimester of pregnancy and 4 months after delivery (lactation) ${ }^{a}$

\begin{tabular}{|c|c|c|c|c|c|c|c|}
\hline \multirow[b]{2}{*}{ Variable } & \multicolumn{3}{|c|}{ Pastoralists } & \multicolumn{3}{|c|}{ Farmers } & \multirow{2}{*}{$\begin{array}{c}p \\
\left(\text { Pearson } \chi^{2}\right)\end{array}$} \\
\hline & $N$ & $\%$ & $95 \% \mathrm{CI}$ & $N$ & $\%$ & $95 \% \mathrm{CI}$ & \\
\hline \multicolumn{8}{|l|}{ Hemoglobin $(\mathrm{g} / \mathrm{L})$} \\
\hline Pregnancy $(<110)$ & 49 & 42.2 & 98-101 & 27 & 21.8 & $102-106$ & $<.01$ \\
\hline Lactation $(<120)$ & 49 & 43.4 & $108-110$ & 31 & 27.7 & $103-109$ & $<.05$ \\
\hline \multicolumn{8}{|l|}{ Ferritin $<32 \mu \mathrm{g} / \mathrm{L}$} \\
\hline Pregnancy & 95 & 77.0 & $23.7-24.5$ & 110 & 85.9 & $22.8-23.5$ & $>.05$ \\
\hline Lactation & 111 & 98.0 & $17.8-18.6$ & 109 & 99.0 & $16.3-17.1$ & $>.05$ \\
\hline \multicolumn{8}{|l|}{ Retinol $<0.70 \mu \mathrm{mol} / \mathrm{L}$} \\
\hline Pregnancy & 34 & 27.9 & $0.41-0.45$ & 31 & 24.2 & $0.47-0.53$ & $>.05$ \\
\hline Lactation & 33 & 29.2 & $0.51-0.56$ & 34 & 30.9 & $0.50-0.55$ & $>.05$ \\
\hline
\end{tabular}

CI, confidence interval

a. There were 122 pregnant and 113 lactating pastoral women and 128 pregnant and 110 lactating farming women. 
maize, sorghum, millet, and beans. Although some areas have irrigation systems, which are communally controlled and maintained, in a drought year the seasonal availability of food is reduced and household food insecurity becomes more acute. No cash crops are grown in the area, and sources of cash for purchase of maize are limited, especially in households where none of the members are formally employed [9].

Between 1989 and 2003, the infant mortality rate in Kenya increased from 60 to 78 per 1,000 births. The increase reflects the deterioration in quality of life over the last 20 years [16]. West Pokot is in the Rift Valley Province, where the infant mortality rate among women who have no education is 73.3 per 1,000 births [16]. In our study, the relative risk of infant death was 2.4 times greater in the farming communities. In both the farming and the pastoral communities, a large proportion of births took place at home. The early identification of infants with low birthweight is essential for any comprehensive initiative aimed at improving child survival. In Ethiopia, chest and head circumference have been used to identify infants with reduced birthweight, and these anthropometric measurements could also be used for this purpose by TBAs in the pastoral and farming Pokot communities [17].

In this study, the mean birthweight of the infants was the same as that of infants born to Turkana pastoral women $(2.9 \mathrm{~kg})$ [8]. The available data on infant birthweight tend to be based on deliveries occurring in hospitals and health centers. According to data from Kenya, the incidence of birthweights less than $2.5 \mathrm{~kg}$ is $9.3 \%$ [16]. An estimate of $11 \%$ has been made for other developing countries. Because of insufficient data, there have been no estimates for the East African region [18], and therefore our data provide valuable information on this topic. Our community-based data confirm the magnitude of the problem of low birthweight. The estimated incidence rates of low birthweight of $16.8 \%$ and $31.3 \%$ for pastoral and farming communities, respectively, in West Pokot are considerably higher than the national estimate based on hospital data. There is a possibility that the incidence of low birthweight was overestimated in our study because of the field conditions under which gestational age was determined. We did not have an effective method of identifying premature births, but a more effective method may be developed in future investigations. In this study the estimated risk of having an infant weighing less than $2.50 \mathrm{~kg}$ was 2.3 times greater for women living in farming communities than for those living in pastoral communities. Being born with low birthweight in a socioeconomically deprived community such as the Pokot farming community leads to negative health consequences that reverberate throughout the life cycle of an individual $[18,19]$. The West Pokot District is one of the 10 poorest districts in Kenya, with about $43 \%$ of its population living at the poverty line $e^{\star}$ and $49 \%$ below the poverty line. Literacy levels have remained low. It is estimated that only $1.1 \%$ of individuals are formally employed [9].

In this study, changes in maternal body weight were minimal. Although a single measurement of maternal weight has been reported to be correlated with low birthweight [11], interpretation of maternal weight is constrained by the fact that it varies according to the mother's health and nutritional status, stage of gestation, physiological condition, and genetic background. Although total weight may be sensitive to these factors, it lacks specificity as an indicator. The large variation in weight within a specific height category has given rise to various expressions of weight-for-height, such as the body-mass index. A very low body-mass index is a fairly accurate reflection of severe wasting of both fat and lean tissue. Weight loss during lactation is variable and depends on socioeconomic status, weight gained during pregnancy, energy intake, and pattern of breastfeeding. Weight losses are highest in the first 3 months of lactation [20].

At 4 months postpartum, $23 \%$ of farming women and $26 \%$ of pastoral women had a body-mass index of less than $18.5 \mathrm{~m} / \mathrm{kg}^{2}$. The level of body-mass index below which there is a risk of poor lactation or infant growth has not been reported. It is possible to estimate a level based on the lower limit of body-mass index $\left(<18.5 \mathrm{~m} / \mathrm{kg}^{2}\right)$ suggested for thin adults, adjusted for the average weight $(4 \mathrm{~kg})$ retained by mothers following an acceptable pregnancy weight gain $(10.5$ to $12 \mathrm{~kg})$ and enough time for postpartum hydration to have equilibrated ( 2 to 4 weeks). In most cases, this results in an estimated cutoff for body-mass index of 20.3 $\mathrm{m} / \mathrm{kg}^{2}$ at 1 month postpartum for women $150 \mathrm{~cm}$ tall. Body-mass index may be expected to decline steadily throughout the first 6 months of lactation, at which point a value of $18.5 \mathrm{~m} / \mathrm{kg}^{2}$ for a nonpregnant, nonlactating woman can be used as a cutoff for identifying women at risk for chronic energy deficiency [11] .

Infections have a profound effect on nutritional status. West Pokot is a malaria-endemic area. During the 2003 Kenya National Demographic and Health Survey, the prevalence of HIV infection among women in the Rift Valley was $9.0 \%$ for those 20 to 24 years of age and $12.9 \%$ for those 25 to 29 years of age [16]. Multiple nutrients may play a role in protecting against or exacerbating malaria. A number of cross-sectional studies have shown an inverse relationship between vitamin A levels and the concentration of malaria parasites in the blood [21]. Earlier studies in which iron was given therapeutically, either as prophylaxis or for the treatment of iron deficiency, suggested that iron supplementation might be associated with an increased

* The poverty line is set as the cost of "normative basic needs" sufficient to reach a predetermined energy requirement. 
incidence of clinical malaria [22,23 ]. This suggestion has not been confirmed in studies conducted more recently $[24,25]$. Nevertheless, a recent meta-analysis has shown that the evidence still favors a small but significantly increased risk of malaria following iron supplementation [26]. Relatively little is known about the converse association - that is , the incidence of malaria among iron-deficient persons. A recent Kenyan study found that the incidence of clinical malaria was significantly lower among iron deficient children and that the incidence of malaria was significantly associated with plasma ferritin concentration [27]. Iron supplementation programs in accordance with international dosing guidelines are appropriate for iron-deficient populations residing in malaria-endemic areas [21].

The prevalence of low maternal hemoglobin concentration $(<110 \mathrm{~g} / \mathrm{L})$ during the third trimester of pregnancy was significantly higher in pastoral than in farming women. The relative risk of low hemoglobin concentration was about 2.6 times higher for women living in pastoral communities than for those living in farming communities. The higher risk among pastoral women may be due not only to nutritional inadequacy but also to the fact that these women are more vulnerable to endemic malaria because they live in a hot savannah climate at lower altitudes. The problem is that infections such as malaria and HIV may induce an acute phase response that may increase serum ferritin concentrations and decrease hemoglobin concentrations. This might be the case for the pastoral Pokot women in our study. Chronic infection is another potential confounder of the biochemical iron indices that were used, and unfortunately we were unable to collect data on acute phase proteins such as C-reactive protein. Failure to consider the effects of the acute phase response results in a distorted estimate of the prevalence of iron deficiency [28]. Our data need to be interpreted with this in mind.

In this study, $25 \%$ of the Pokot women were found to have serum retinol concentrations of less than 0.70 $\mu \mathrm{mol} / \mathrm{L}$ during pregnancy. In a national demographic survey carried out in 2003, $11.6 \%$ of pregnant women were reported to be night-blind [16]. Night-blindness is considered a proxy indicator of vitamin A status. Just as reported for iron indices $[28,29]$, surveys to estimate

\section{References}

1. Mejia LA. Role of vitamin A in iron deficiency anemia. In: Nutritional anemia. Fomon SJ, Zlotkin S, eds. Nestle Nutrition Workshop Series Vol 30. New York: Raven Press, 1992:93-101.

2. Dijkhuizen MA, Wieringa FT, West CE, Muherdiyantiningsih, Muhilal. Concurrent micronutrient deficiencies in lactating mothers and their infants in Indonesia. Am J Clin Nutr 2001;73:786-91.

3. Suharno D, West CE, Muhilal, Karyadi D, Hautvast vitamin A deficiency should also include measurements of serum C-reactive protein. Omission of this assessment may have affected our estimates of serum retinol. A study by Sapin et al. [30] found that healthy, wellnourished pregnant women who reached full term had the same absolute quantities of retinol as nonpregnant women and that the lower concentrations of retinol in pregnant women who had reached full term were due to expansion of plasma volume.

In conclusion, life in the Pokot communities remains harsh and traditional. It is a life associated with poverty. The Pokot farming way of life was associated with negative changes in maternal body composition, iron stores, and vitamin A status during the third trimester of pregnancy and at 4 months after delivery. These factors may have partially determined pregnancy outcome. Pastoral and farming women were equally affected by the high prevalence of vitamin A deficiency and low iron stores. Although we recommend that intervention strategies aim at preventing reductions in maternal body composition and infant birthweight, we also point out that associations do not prove causality. Clearly the body composition, serum retinol concentration, and ferritin concentration of the women, especially of the farming women, are the result of complex interactions between physiological and environmental factors that may include low caloric intakes, high levels of physical activity, and coexisting diseases.

\section{Acknowledgments}

This study was carried out within the framework of the Moi University and Maastricht University Centre for International Cooperation in Academic Development and Nutrition and Toxicology Research Institute Maastricht (MUNDO/NUTRIM) project. We are grateful for the facilitation role played by the dean of the Faculty of Health Sciences, Prof. B. O. Khwa-Otsyula, and the former dean, Prof. H. N. K. arap Mengech. Special thanks go to the chief, the village committees, and the mothers of the West Pokot communities. Special mention is made of Ms. H. Chesopo, who provided invaluable support in sample collection, and Mr. M. Sang and Mr. L. C. Kimile for facilitating sample analysis.

JG. Supplementation with vitamin A and iron for nutritional anaemia in pregnant women in West Java, Indonesia. Lancet 1993;342(8883):1325-8.

4. Muslimatun S, Schmidt MK, Schultink W, West CE, Hautvast JA, Gross R, Muhilal. Weekly supplementation with iron and vitamin A during pregnancy increases hemoglobin concentration but decreases serum ferritin concentration in Indonesian pregnant women. J Nutr 2001;131:85-90. 
5. Pike IL. Age, reproductive history, seasonality, and maternal body composition during pregnancy for nomadic Turkana of Kenya. Am J Hum Biol 1999;11:658-72.

6. Ettyang GA, van Marken Lichtenbelt WD, Esamai F, Saris WH, Westerterp KR. Assessment of body composition and breast milk volume in lactating mothers in pastoral communities in Pokot, Kenya, using deuterium oxide. Ann Nutr Metab 2005;49:110-7.

7. Leslie PW, Campbell KL, Little MA. Pregnancy loss in nomadic and settled women in Turkana, Kenya: a prospective study. Hum Biol 1993;65:237-54.

8. Pike IL. Pregnancy outcome for nomadic Turkana pastoralists of Kenya. Am J Phys Anthropol 2000;113:31-45.

9. Pkosing D, Krop S, Lopetakou W, Sikamov P. The Pokot land claims in Trans Nzoi District (1896-2002). Presented to the Constitution of Kenya Review Commission. Available at: http://www.kenyaconstitution.org. April 2002. Accessed 19 June 2006.

10. Kramer MS, McLean FH, Boyd ME, Usher RH. The validity of gestational age estimation by menstrual dating in term, preterm, and postterm gestations. JAMA 1988;260:3306-8.

11. Maternal anthropometry and pregnancy outcomes. A WHO Collaborative Study. Bull World Health Organ 1995;73(suppl):1-98.

12. Maternal nutrition and pregnancy outcome: anthropometric assessment. Scientific publication no. 529. Krasovec K, Anderson MA, eds. Washington, DC: Pan American Health Organization, 1991.

13. Gibson R. Principles of nutritional assessment. New York: Oxford University Press, 1990.

14. Yip R. Iron deficiency: contemporary scientific issues and international programmatic approaches. J Nutr 1994; 124( 8 suppl):1479S-90S.

15. World Health Organization. Indicators for assessing vitamin A deficiency and their application in monitoring and evaluating intervention programmes. WHO/ NUT/96.10. Geneva: WHO, 1996.

16. Central Bureau of Statistics, Kenya. The Kenya Demographic and Health Survey 1993. Available at: http:// www.cbs.go.ke. Accessed 19 June 2006.

17. Raymond EG, Tafari N, Troendle JF, Clemens JD. Development of a practical screening tool to identify pre-term, low-birthweight neonates in Ethiopia. Lancet 1994;344(8921):524-7.

18. United Nations Administrative Committee on Coordination/Sub-Committee on Nutrition (ACC/SCN). Fourth report on the world nutrition situation. Nutrition throughout the life cycle. Geneva: ACC/SCN and International Food Policy Research Institute (IFPRI), 2000 .
19. Allen LH, Lunga'aho MS, Shaheen M, Harrison GG, Neumann C, Kirksey A. Maternal body mass index and pregnancy outcome in the Nutrition Collaborative Research Support Program. Eur J Clin Nutr 1994;48(suppl 3):S68-76; discussion S76-7.

20. Brewer MM, Bates MR, Vannoy LP. Postpartum changes in maternal weight and body fat deposits in lactating vs nonlactating women. Am J Clin Nutr 1989;49:259-65.

21. Paton NI, Gassull MA, Cabre E. Infectious disease. In: Clinical Nutrition. Gibney MJ, Marinos E, Ljungqvist O, Dowsett J, eds. 1st ed. Oxford: Blackwell Science, 2005:324-44.

22. Oppenheimer SJ, Gibson FD, Macfarlane SB, Moody JB, Harrison C, Spencer A, Bunari O. Iron supplementation increases prevalence and effects of malaria: report on clinical studies in Papua New Guinea. Trans R Soc Trop Med Hyg 1986;80:603-12.

23. Smith AW, Hendrickse RG, Harrison C, Hayes RJ, Greenwood BM. The effects on malaria of treatment of iron deficiency anaemia with oral iron in Gambian children. Ann Trop Paediatr 1989;9:17-23.

24. Verhoef H, West CE, Nzyuko SM de Vogel S, van der Valk R, Wanga MA, Kuijsten A, Veenemans J, Kok FJ. Intermittent administration of iron and sulfadoxine-pyrimethamine to control anaemia in Kenyan children: A randomised controlled trial. Lancet 2002;360(9337):908-14.

25. Desai MR, Mei JV, Kariuki SK, Wannemuehler KA, Phillips-Howard PA, Nahlen BL, Kager PA, Vulule JM, ter Kuile FO. Randomized, controlled trial of daily iron supplementation and intermittent sulfadoxine-pyrimethamine for the treatment of mild childhood anemia in western Kenya. J Infect Dis 2003;187:658-66.

26. Shankar AH. Nutritional modulation of malaria morbidity and mortality. J Infect Dis 2000;182(Suppl 1): S37-53.

27. Nyakeriga AM, Troye-Blomberg M, Dorfman JR, Alexander ND, Back R, Kortok M, Chemtai AK, Marsh K, Williams $\mathrm{TN}$. Iron deficiency and malaria among children living on the coast of Kenya. J Infect Dis 2004;190:439-47.

28. Thurnham DI, McCabe GP, Northrop-Clewes CA, Nestel P. Effects of subclinical infection on plasma retinol concentrations and assessment of prevalence of vitamin A deficiency: meta-analysis. Lancet 2003;362(9401):2052-8.

29. Wieringa FT, Dijkhuizen MA, West CE, NorthropClewes CA, Muhilal. Estimation of the effect of the acute phase response on indicators of micronutrient status in Indonesian infants. J Nutr 2002;132:3061-6.

30. Sapin V, Alexandre MC, Chaib S, Bournazeau JA, Sauvant P, Borel P, Jacquetin B, Grolier P, Lemery D, Dastugue $\mathrm{B}$, Azais-Braesco V. Effect of vitamin A status at the end of term pregnancy on the saturation of retinol binding protein with retinol. Am J Clin Nutr 2000;71:537-43. 